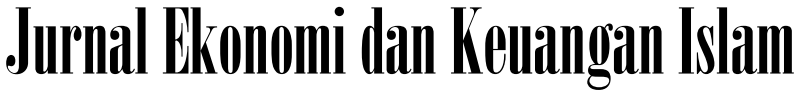

Available at https://journal.uii.ac.id/jeki

\section{A spatial analysis of non-performance financing determinants in Islamic banks in Indonesia}

\author{
Eko Suprayitno $^{1}$; Rizky Mubarocha Hardiani ${ }^{2}$ \\ 1,2Faculty of Economics, Maulana Malik Ibrahim State Islamic University Malang, Malang, Indonesia
}

\author{
Article History \\ Received : 8 June 2021 \\ Revised : 18 June 2021 \\ Accepted : 28 June 2021 \\ Published : 10 July 2021 \\ Keywords: \\ Islamic bank; non-performing \\ financing; spatial analysis; \\ microeconomic variables, \\ macroeconomic variables \\ DOI: \\ https://doi.org/10.20885/JEKI.vol7.is \\ s2.art7
}

JEL Clasification:

G21; E10; C21

Corresponding author:

suprayitno@pbs.uin-malang.ac.id

Author's email:

rizzmho34@gmail.com

Paper type:

Research Paper

Cite this article:

Suprayitno, E., \& Hardiani, R. M. (2021). A spatial analysis of non-performance financing determinants in Islamic banks in Indonesia. Jurnal Ekonomi dan Keuangan Islam, 7(2), 189-205. https://doi.org/10.20885/JEKI.vol7.is s2.art7

\section{Introduction}

Islamic banks are financial institutions which also have obligations to their stakeholders. The obligation is to disclose information in a timely, adequate, precise, accurate, and comparable manner and easily accessible to stakeholders (Amaroh, 2016; Amaroh \& Masturin, 2018). It can be in the form of financial statements or other supporting reports. Furthermore, from the report, stakeholders can assess the performance of a financial institution/Islamic bank based on the reporting time. In assessing the performance of a financial institution/Islamic bank, an assessment or measurement of the institution's performance itself.

The main function of the bank as a financial institution is that the bank acts as a financial intermediary between parties who have excess funds (surplus units) and those who need funds

\begin{abstract}
Purpose - This study aims to analyze the non-performance financing determinant of Islamic Banking (IB) in Indonesia through spatial analysis. These determinants consist of macroeconomic and microeconomic variables
\end{abstract}

Methodology - Samples in this research were selected using the purposive sampling technique with the criteria of Islamic banks registered in the Financial Services Authority (OJK) that released quarterly data reports and financial reports during 2015-2020. There are 7 Islamic banks that met the criteria.

Findings - Results showed that the ROA, Inflation, GDP, and BI Rate simultaneously affected the NPF level, while FDR and CAR do not affect the NPF level of Islamic commercial banks. Meanwhile, partially FDR, BOPO, CAR, ROA, Inflation, GDP, and BI Rate affect the NPF level. In addition, the spatial analysis showed that based on the global distribution, there is a significant spatial effect through the geographical location between one bank and other.

Originality - This research provides empirical data related to the determinants of non-performing financing, using the spatial analysis approach. Moreover, this research also uses the most updated data, Islamic and conventional banks during 2015-2020

Research limitations - Related to the samples of Islamic banks, this research only investigates those registered in OJK, not all Islamic banks in Indonesia. 
(deficit units) (Hernawati \& Puspasari, 2018). As an intermediary institution, the bank acts as an intermediary between parties who have excess funds and those who need funds. Most banks in Indonesia still use financing as their main source of income. In carrying out the business activities of Islamic commercial banks, which include disbursement of financing, of course, all of these financings are not free from risk, which is commonly known as financing risk. If this risk does occur, it will threaten the sustainability of the bank and affect the soundness of the bank as measured by indications of banking financial performance. In Islamic banks, the level of nonperforming financing can be shown by the ratio of Non-Performing Financing (NPF) (Auliani \& Syaichu, 2016).

Non-Performing Financing (NPF) shows the magnitude of the financing risk faced by Islamic banks. Meanwhile, Non-Performing Loans (NPLs) indicate credit risk in conventional banks. Based on Bank Indonesia regulations, non-performing financing (Non-Performing Financing) is financing with substandard, doubtful, and non-performing quality (PBI No. 6/9/PBI/2004). Non-performing financing (NPF) is financing that has difficulty in repayment due to factors or there is an element of intent or because of conditions beyond the ability (Mazri et al., 2018; Wiyadi et al., 2016). This non-performing financing has an impact on the costs borne by the bank will be even greater so that the cash flow that occurs in the bank will be disrupted. This can potentially be a loss for the bank so that the profits obtained will decrease (Wibowo \& Saputra, 2017).

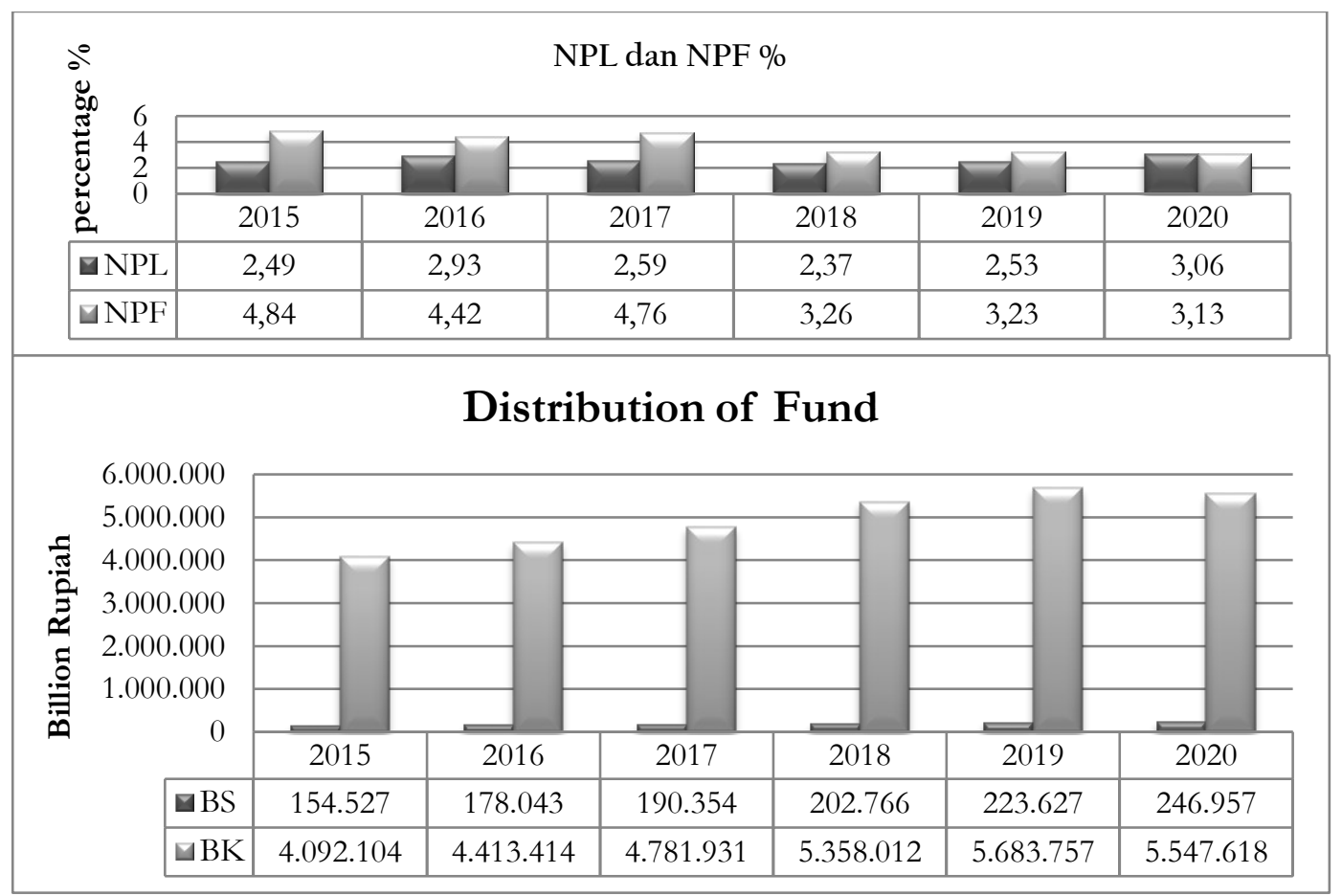

Figure 1. NPL/NPF level and distribution of funds on Islamic and conventional banks

Figure 1 shows that the NPF ratio of Islamic banks is always higher than that of conventional banks. Meanwhile, the level of disbursement of funds in conventional banks is higher than that in Islamic banks. In 2015 the data obtained from the statistics of Islamic banking at the level of Non-Performing Financing (NPF) was considered unsatisfactory. This is because the NPF level of Islamic banks has increased sharply to reach the normal limit set by the Financial Services Authority (OJK), which does not exceed 5\%. The NPF level of Islamic banks in 2015 reached 4.84\%, even throughout 2015 the NPF level of Islamic banks was more than 5\%. Although in 2018 the NPF level of Islamic banks gradually improved to $3.26 \%$. Meanwhile, the NPL level at conventional banks in 2015 was $2.49 \%$.

This phenomenon has become a concern for the management of Islamic banks so that they need more attention to overcome the non-performing financing that occurs. Looking at Indonesian 
banking statistics, the NPL level of conventional banks in 2015-2020 only ranged from $2 \%$ to 3\%, while the NPF of Islamic banks ranged from 3\% to 4\% in 2015-2020. This shows that the level of non-performing loans in conventional banks tends to be more stable than non-performing financing in Islamic banks.

The level of non-performing financing that occurs can be caused by various factors, such as micro or macroeconomic factors (Wibowo \& Saputra, 2017). Microeconomic factors usually start from the bank's operational activities which are stated in its financial performance. Meanwhile, macroeconomic factors occur due to monetary policy and fiscal policy by the government in a country. Demand for financing is closely related to national economic conditions. Healthy economic conditions will support the stability of the national economy to encourage people to make loans to banks (Putri, 2020).

When economic conditions improve, or there is an increase in GDP growth, the NPF level is expected to decrease due to an improvement in the debtor's ability to pay for its financing (Mahdi, 2019). By looking at the size of GDP in a country, it can be seen that how goods or services are produced by a country. If the GDP of a country is good, the welfare of the people will also improve. By channeling funds to the community accompanied by a good economic improvement, financing will tend to generate profits (Wibowo \& Saputra, 2017).

According to Ahmadi et al. (2017), GDP variable had a significant positive effect on NPL. In addition to that, a study on an international scale carried out by Rahmah and Armina (2020) found that monetary factors such as GDP have a significant influence on the NPF of Islamic banks, this is because GDP can still be measured in the short term. In contrast with Purwaningtyas and Hartono (2020) which states that the GDP variable does not affect the NPF. This is based on the uneven growth of GDP in all sectors which results in no effect of GDP on the NPF.

This research is expected to make a conceptual contribution to non-performing financing, especially about spatial effects that are different from previous researchers. The novelty of the results of this study is the possibility of a spatial effect on non-performing financing that occurs in neighboring provinces. From the problems that have been presented, the purpose of this study is to determine the spatial effect of macro and micro factors on non-performing financing in Islamic Commercial Banks in Indonesia. On a practical level, the influence of internal micro variables in Islamic banking will provide a practical overview of the internal conditions of Islamic banks and determine reactive innovation strategies to excel in controlling the market.

\section{Literature Review}

\section{Non-Performing Financing (NPF)}

The banking world often encounters cases such as non-performing loans or bad loans, in Islamic banking, the term is known as non-performing financing. Problem financing is a condition in which during the financing period a financing condition occurs, namely the existence of a major deviation in terms of payment that causes delays in payment or legal action is required in return or potential loss (Sudarsono \& Saputri, 2018; Usanti \& Shomad, 2013). The decline in the quality of financing does not occur suddenly, but first, there is a warning sign. Factors that can cause non-performing financing are grouped into two, namely internal and external factors. Internal factors come from the bank. Meanwhile, external factors come from customers, natural disasters, and government policies (Hernawati \& Puspasari, 2018). NPF is an indicator that can be used to measure financing risk in Islamic banks. NPF is the ratio between non-performing financing and total financing disbursed by Islamic banks (Dendawijaya, 2003; Kuncoro, 2002).

Bank Indonesia sets the criteria for non-performing financing based on PBI No. 8/21/PBI/2006 dated October 5, 2006, regarding the quality assessment of commercial banks that carry out business activities based on sharia principles article 9 paragraph (2), that the quality of earning assets in the form of financing is divided into 5 groups, namely: Current (L), In Attention Special (DPK), Substandard (KL), Doubtful (D), and Loss (M). The NPF ratio shows the quality of financing carried out by a bank, the higher the NPF ratio, the quality of financing provided by a bank is getting worse. 
Sharia bank officers who are authorized or responsible for disbursing financing need to understand the principles of financing, namely the 5C. According to Amiruddin (2018), the first is Character, which is an analysis to determine the nature or character of a customer applying for financing. The second is Capacity, which is an analysis used to see the financial ability of prospective customers in fulfilling their obligations according to the financing period. The third is Capital, which is to assess the capital owned by prospective customers to finance credit. The fourth is Collateral, which is provided by the prospective customer for the proposed financing. The fifth is Condition of Economic, which is an assessment of market conditions at home and abroad to determine the marketing prospects of the business results of the financed customers.

While the financing assessment using the $7 \mathrm{P}$ analysis method according to Amiruddin (2018) includes Personality, which means assessing customers in terms of their personality or their daily and past behavior. Party, which means classifying customers into certain classifications or certain groups based on their capital, loyalty, and character. Purpose, which is to know the customer's purpose in taking financing, including the type of financing that the customer wants. Prospect, which is to assess the customer's business in the future whether it is profitable or not, has prospects or not. Payment is a measure of how the customer returns the credit that has been taken or from any source of funds for credit repayment. Profitability is to analyze how the customer's ability to find customers. Protection which aims to keep businesses and guarantees getting protection (Usanti \& Shomad, 2013).

According to the Financial Services Authority Regulation Number 15/POJK.03/2017, banks are considered to have potential difficulties that endanger business sustainability if the ratio of NPF is more than $5 \%$ of the total credit or total financing, which means that the limit on the ratio of credit or NPF in conventional banking and Islamic banking is 5\% (Table 1).

Table 1. NPF Assessment Criteria

\begin{tabular}{ll}
\hline \multicolumn{1}{c}{ Criteria } & \multicolumn{1}{c}{ Information } \\
\hline Rank 1: NPF $<7 \%$ & Very Low \\
Rank 2: $7 \%<\mathrm{NPF}<10 \%$ & Low Enough \\
Rank 3: $10 \%<\mathrm{NPF}<13 \%$ & Low \\
Rank 4: $13 \%<\mathrm{NPF}<16 \%$ & High Enough \\
Rank 5: NPF $>16 \%$ & High \\
\hline
\end{tabular}

Source: Financial Services Authority, 2019)

\section{Hypothesis Development}

In general, factors that can cause non-performing financing are divided into two, internal and external factors. Internal factors come from the bank, and the most dominant factor is the managerial factor. External factors come from customers, natural disasters, wars, change in economic, trade conditions, technological changes, and government policies. The emergence of the company's financial difficulties was caused by several factors, such as weakness in purchasing and selling policy, supervision of costs and expenses, inappropriate accounts receivable policy, excessive placement of fixed assets, and insufficient capital (Hosen \& Muhari, 2019; Mahdi, 2019; Rahmah \& Armina, 2020; Yulianto \& Solikhah, 2015).

\section{Relationship between Financing to Deposit Ratio (FDR) and Non-Performing Financing (NPF)}

FDR is used to see the ability of a bank to repay withdrawals made by depositors through credit provided as a source of liquidity (Badria \& Marlius, 2019). FDR is a financial ratio of banking companies used to measure the ratio between the financing provided to the public and the funds received by the bank (Sudarsono \& Saputri, 2018; Wibowo \& Saputra, 2017). FDR is the bank's ability to repay the withdrawal funds that have been made by depositors using credit provided by the bank with funds received by the bank (Badria \& Marlius, 2019). So the higher the FDR ratio, the possibility of non-performing financing will also increase because almost all of the funds owned 
are used for financing. Research conducted by Astrini et al. (2018), states that simultaneously and partially, the FDR variable has a significant effect on the level of non-performing financing.

$\mathrm{H}_{1}$ : Financing to Deposit Ratio (FDR) has a positive effect on the Non-Performing Financing (NPF)

\section{Relationship between Operating Costs to Operating Income (BOPO) and Non- Performing Financing (NPF)}

$\mathrm{BOPO}$ is the ratio between operating costs to operating income. Operational costs are used to measure the level of efficiency and ability of the bank in carrying out its operational activities (Chandra \& Haryanto, 2016; Hameed et al., 2004). The BOPO ratio is closely related to the operational activities of Islamic banks, namely collecting and distributing funds. A large BOPO means that the operational costs borne as a result of non-performing financing are greater than the operating income received from the compensation or profit-sharing that has been provided. Operational costs of Islamic banks that are too high with low operating costs can reduce the BOPO ratio so that Islamic banks are in a healthy position, which means that the tendency for nonperforming financing will also be low (Auliani \& Syaichu, 2016). This BOPO ratio is the most commonly used ratio to measure efficiency in the banking industry. The greater the BOPO ratio, the smaller or lower the financial performance of banks. Conversely, the smaller the BOPO ratio means the more efficient the bank's operational performance in carrying out its daily operations so that the probability of a bank in difficult conditions will be smaller. Research conducted by Angraini et al. (2020), Auliani and Syaichu (2016), Fatoni and Utami (2019), Rahman and Fatmawati (2020), Santosa et al. (2014), and Wibowo and Saputra (2017) states that BOPO has a positive effect on non-performing financing in banks.

$\mathrm{H}_{2}$ : Operational Costs on Operating Income (BOPO) has a positive effect on Non-Performing Financing (NPF)

\section{Relationship between Capital Adequacy Ratio (CAR) and Non-Performing Financing (NPF)}

CAR is a capital ratio that shows the bank's ability to provide funds for business development purposes and accommodate the risk of loss of funds caused by bank operations (Wibowo \& Saputra, 2017; Widarjono \& Rudatin, 2021). A high CAR ratio can indirectly increase customer safety and trust, which may have a positive impact on increasing profitability. CAR is a ratio that shows how far all bank assets that contain risks (credit, investments, securities, claims on other banks) are also financed from own capital funds, in addition to obtaining funds from sources outside the bank, such as public funds, loans, and others. The CAR ratio is related to the capital aspect, namely the ratio of the capital to the weighted assets ratio. If the CAR ratios shows a higher number, the better the bank's ability to bear the risk of any risky credit or productive assets. Study conducted by Fatoni and Utami (2019), Purwaningtyas and Hartono (2020), and Widarjono and Rudatin (2021) states that capital, as measured by CAR, influences the NPF of Islamic banks in Indonesia.

$\mathrm{H}_{3}$ : Capital Adequacy Ratio (CAR) has a positive effect on Non-Performing Financing (NPF)

\section{Relationship between Return on Assets (ROA) and Non-Performing Financing (NPF)}

$\mathrm{ROA}$ is a ratio that shows the results (return) on the amount used in the company or a measure of management activities (Kasmir, 2015). ROA is the ratio used to measure the ability of bank management to obtain overall profit (Badria \& Marlius, 2019). The ROA ratio is related to the bank's profitability ratio. ROA is a financial ratio related to the profitability of Islamic banking, which is a measurement of the company's ability to generate profits at a certain level of income, assets, and share capital. The size of the ROA value can reflect the results of certain company policies, especially in the banking sector (Nugrohowati \& Bimo, 2019; Putrama \& Asandimitra, 2017; Rahman \& Fatmawati, 2020). A high ROA value indicates a company is more efficient in utilizing its assets to earn a profit. The higher the return on assets, the higher the amount of profit 
that will be generated. Conversely, the lower the return on assets, the lower the amount of profit generated. According to research conducted by Fatoni and Utami (2019), and Nawaz and Haniffa (2017), the ROA variable has no significant effect on NPF in Islamic banks.

\section{$\mathrm{H}_{4}$ : Return on Assets (ROA) has a negative effect on Non-Performing Financing (NPF)}

\section{Relationship between Inflation and Non-Performing Financing (NPF)}

Inflation is the process of increasing the price of goods in general and continuously over a period measured by using a price index. However, if the price increase is only for one or two goods, it is not called inflation, unless the increase is widespread or causes an increase in most of the prices of other goods (Boediono, 1999; Nopirin, 2004; Reksoprayitno, 2000). Inflation occurs because the growth in the amount of money exceeds the growth in real factors so that people's purchasing power decreases. Therefore, it can be said that inflation affects economic activities in a country both macro and micro (Nugrohowati \& Bimo, 2019). A high inflation rate will cause a decrease in people's real income so that people's living standards will also decrease, before inflation a debtor is considered able to pay his installments, but after inflation occurs which makes prices increase, the debtor's ability to pay will decrease because partly Most of the income is used for basic needs. The occurrence of inflation will have an impact on the banking sector because some debtors will have difficulty paying their loan installments. Therefore, the higher the inflation rate in a country will cause non-performing financing to increase. According to research conducted by Angraini et al. (2020), and Hosen and Muhari (2019), inflation affects the level of non-performing financing.

$\mathrm{H}_{5}$ : Inflation has a positive effect on Non-Performing Financing (NPF)

\section{Relationship between Gross Domestic Product (GDP) and Non-Performing Financing (NPF)}

GDP is the total value or market price of all final goods and services produced by an economy during a certain period (usually one year) (Boediono, 1999; Nopirin, 2004; Reksoprayitno, 2000). GDP is the result of the sum of all goods and services produced by all people (including foreign nationals) in a country for a certain period. GDP measures the value of goods and services produced in a country regardless of nationality over a certain period. In the banking sector, the demand for financing is closely related to national economic conditions. Healthy economic conditions will support the stability of the national economy to encourage people to make loans to banks (Hosen \& Muhari, 2019; Naibaho \& Rahayu, 2018; Rahmah \& Armina, 2020). A high level of GDP will affect non-performing financing because most customers will be more concerned with meeting consumption needs first than paying off debt. The pace of GDP growth is driven by a series of economic activities including public consumption, investment, government spending, and exports and imports which will ultimately determine the demand for financing for the banking sector (Boediono, 1999; Reksoprayitno, 2000). According to research conducted by Ahmadi et al. (2017), and Rahmah and Armina, (2020), monetary factors such as GDP have a significant influence on the NPF of Islamic banks.

$\mathrm{H}_{6}$ : Gross Domestic Product (GDP) has a negative effect on Non-Performing Financing (NPF)

\section{Relationship between BI rate and Non-Performing Financing (NPF)}

BI Rate as interest applied to customers on the price to be paid to the bank because the bank has provided services (Boediono, 1999; Nopirin, 2004; Reksoprayitno, 2000). The BI rate is the determination of the interest rate as a result of policies that reflect monetary policy and is determined by Bank Indonesia and is widely published. The BI rate shows an indication of the short-term interest rate that Bank Indonesia wants to achieve to achieve the inflation target. The $\mathrm{BI}$ rate is used as a reference to direct the interest rate for 1-month Bank Indonesia Certificates (SBI) resulting from open market operations auctions to be around the BI rate (on the website www.bi.go.id) (Hosen \& Muhari, 2019; Prasetyoningrum, 2015; Mutia et al., 2019; Naibaho \& Rahayu, 2018). The BI rate is the reference interest rate announced by Bank Indonesia periodically for a certain period which serves as a stance or signal for monetary policy. If the BI rate increases, 
Islamic banks will automatically adjust the profit-sharing rate, because indirectly the BI rate becomes a reference for Islamic banks in determining the profit-sharing margin. Determination of the equivalence rate often refers to the $\mathrm{BI}$ rate where when there is an increase in loan interest rates, it will increase the equivalent rate. A high equivalence rate will reduce customer interest in applying for financing. This will burden the debtor when paying the equivalent rate and the principal of the financing, thereby reducing the financing risk (Fatoni \& Utami, 2019; Nawaz \& Haniffa, 2017; Nugrohowati \& Bimo, 2019). Research conducted by Hernawati and Puspasari (2018), and Naibaho and Rahayu (2018) concludes that the BI rate has a positive and significant effect on non-performing financing.

$\mathrm{H}_{7}$ : BI Rate has a positive effect on Non-Performing Financing (NPF)

\section{Research Methods}

This study takes data obtained from Bank Indonesia, the Central Bureau of Statistics and Statistics of Islamic Banking provided by OJK as well as the website of Islamic Commercial Banks to obtain financial reports of Islamic Commercial Banks and the website of Islamic banking statistics. The sample data used is quarterly data from all BUS in Indonesia during 2015-2020.

\section{Population and Sample}

The population used in this study is all Islamic Commercial Banks in Indonesia from 2015 to 2020 with data taken from the SPS (Islamic Banking Statistics) totaling 14 BUS. The data used is quarterly data from all BUS in Indonesia during 2015-2020. The total sample was 168 items. Meanwhile, macroeconomic variables were obtained from BPS (Central Statistics Agency). In this study, samples were taken using the purposive sampling method. Table 2 shows that the sample criteria in this study are as follows:

Table 2. Criteria for Islamic commercial banks

\begin{tabular}{llc}
\hline No. & \multicolumn{1}{c}{ Islamic Commercial Bank Criteria } & Amount \\
\hline 1. & Islamic Commercial Banks registered in Financial Services Authority (OJK) & 14 \\
2. & Islamic Commercial Bank did not operate in 2015 is: & $(1)$ \\
1. PT Bank BPD Nusa Tenggara Barat Syariah & $(6)$ \\
3. & $\begin{array}{l}\text { Islamic Commercial Banks that do not publish their quarterly financial } \\
\text { reports consecutively in the period of 2015-2020 are: }\end{array}$ & \\
1. PT Bank Jabar Banten Syariah & \\
2. PT Bank BNI Syariah & \\
3. PT Bank Mandiri Syariah & \\
4. PT Bank Mega Syariah & \\
5. PT Maybank Syariah Indonesia & 7 \\
6. PT Bank BTPN Syariah & \\
\hline
\end{tabular}

Based on the criteria set out above, Table 3 shows that the Islamic Commercial Banks (BUS) used as samples in this study are as follows:

Table 3. Research sample

\begin{tabular}{ll}
\hline No. & \multicolumn{1}{c}{ Name of Islamic Commercial Bank } \\
\hline 1. & PT Bank BRI Syariah \\
2. & PT Bank Panin Dubai Syariah \\
3. & PT Bank Aceh Syariah \\
4. & PT Bank Muamalat Indonesia \\
5. & PT Bank Victoria Syariah \\
6. & PT Bank Bukopin Syariah \\
7. & PT Bank BCA Syariah \\
\hline
\end{tabular}




\section{Variable Operational Definition}

Research variables are divided into independent variables and dependent variables. The independent variable is a predictor variable that affects or causes changes in the dependent variable. Meanwhile, the dependent variable which is also called the criterion variable is the main factor in conducting the investigation. Summary of operational variables can be described in Table 4.

Table 4. Summary of Operational Variables

\begin{tabular}{|c|c|c|c|c|}
\hline No. & Variable & Variable Definition & Measurement & Indicator \\
\hline \multicolumn{5}{|c|}{ Independent variable } \\
\hline 1. & $\begin{array}{l}\text { Financing to } \\
\text { Deposit ratio } \\
\text { (FDR) }\end{array}$ & $\begin{array}{l}\text { Ratio to measure the risk of a bank's } \\
\text { failure to repay its depositors. }\end{array}$ & FDR $=\frac{\text { Average total financing }}{\text { Average total Deposit }}$ & Percent \\
\hline 2. & $\begin{array}{l}\text { Operating } \\
\text { Expenses and } \\
\text { Operating Income } \\
\text { (BOPO) }\end{array}$ & $\begin{array}{l}\text { Ratio to measure the level of } \\
\text { efficiency and ability of the bank in } \\
\text { carrying out its operations. }\end{array}$ & BOPO $=\frac{\text { Operating Expenses }}{\text { Operational Income }}$ & Percent \\
\hline 3. & $\begin{array}{l}\text { Capital Adequacy } \\
\text { Ratio (CAR) }\end{array}$ & $\begin{array}{l}\text { Ratio to measure how far all bank } \\
\text { assets contain risk. }\end{array}$ & $\mathrm{CAR}=\frac{\text { Capital }}{\text { Risk Weighted Assets }}$ & Percent \\
\hline 4. & $\begin{array}{l}\text { Return On Assets } \\
\text { (ROA) }\end{array}$ & $\begin{array}{l}\text { Ratio to measure the estimated net } \\
\text { income obtained with total existing } \\
\text { assets. }\end{array}$ & ROA $=\frac{\text { Net Income }}{\text { Total Assets }}$ & Percent \\
\hline 5. & Inflation & $\begin{array}{l}\text { Inflation measure an increase in the } \\
\text { price of goods caused by a large } \\
\text { amount of money in circulation } \\
\text { compared to the number of goods } \\
\text { and services offered. }\end{array}$ & 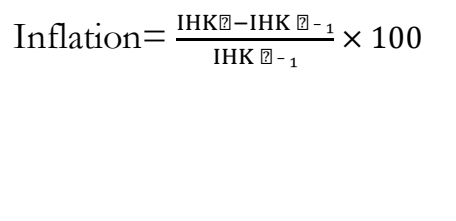 & Percent \\
\hline 6. & $\begin{array}{l}\text { Gross Domestic } \\
\text { Product (GDP) }\end{array}$ & $\begin{array}{l}\text { GDP measures the value of goods } \\
\text { and services produced in a country } \\
\text { regardless of nationality at a certain } \\
\text { period. }\end{array}$ & $\begin{array}{l}\text { Real GDP quarterly data } \\
\text { (quarter) }\end{array}$ & Billion \\
\hline 7. & BI Rate & $\begin{array}{l}\text { BI rate to measure the benchmark } \\
\text { interest rate announced by Bank } \\
\text { Indonesia periodically for a certain } \\
\text { time. }\end{array}$ & $\begin{array}{l}\text { Bank Indonesia Interest Rate } \\
\text { Quarterly (quarter) data }\end{array}$ & Percent \\
\hline \multicolumn{5}{|c|}{ Dependent variable } \\
\hline & $\begin{array}{l}\text { Non-Performing } \\
\text { Financing (NPF) }\end{array}$ & $\begin{array}{l}\text { Ratio to measure non-performing } \\
\text { financing with total financing } \\
\text { disbursed by Islamic banks. }\end{array}$ & $\mathrm{NPF}=\frac{\text { Collective Financing }}{\text { Total Financing }}$ & Percent \\
\hline
\end{tabular}

\section{Spatial Autocorrelation}

Many scholars and researchers make studies on spatial analysis statistics. Most of them are interested in the form of autocorrelation, which means that there is a dependence on the measurement of spatial data from spatial observations. Because of this dependence, "classical" statistical modeling and "spatial" modeling are different from each other (LeSage \& Pace, 2009). This method is fundamental to obtain information about the pattern of distribution of the characteristics of an area and the interrelationships between locations within it. In addition, this method is also used for the identification of spatial modelling (Dubé \& Legros, 2014). Figure 2 shows that the main focus of this study is to prioritize the spatial role based on the following concept (Mufraini et al., 2020): 

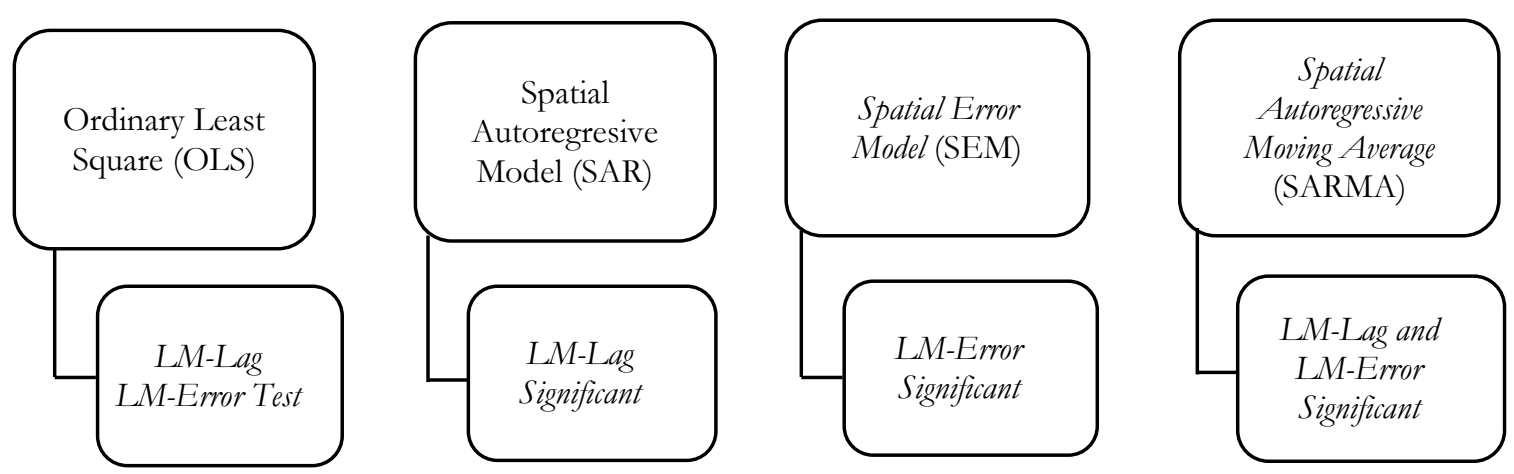

Source: Adopted from Anselin, (2005)

Figure 2. Concept of spatial regression model

Based on the type of spatial data, there are two types of spatial modeling, namely spatial modeling based on points and spatial modeling based on region (Mariani et al., 2017). The spatial autoregressive model (SAR) is a spatial model based on region. The spatial regression model can describe the relationship between the independent variable $(\mathrm{X})$ and the dependent variable $(\mathrm{Y})$ with involves the location effect of the data. That general model of spatial regression is called SARMA (Spatial Autoregressive Moving Average). Several statistics used to calculate the spatial autocorrelation are The Moran Coefficient (Moran's I - MC) and Geary Ratio (Geary's C - GR). In this study, we only use k global index statistics (Moran's I - MC) (Anselin, 2005; LeSage \& Pace, 2009).

\section{Moran Global Index}

This test is used to see spatial aspects or spatial aspects which include several factors such as location factors, natural conditions, and socio-cultural conditions of the surrounding community. In calculating this coefficient, which is based on spatial weight, the following equation is used. Here, wij refers to the $\mathrm{W}$ component row of the standard weight matrix; n number of sampling units, and y corresponding variables (Anselin, 1995, 2019; LeSage \& Pace, 2009).

$$
I=\frac{n \sum_{i} \sum_{i \neq j} w_{i j}\left(y_{i}-\bar{y}\right)\left(y_{j}-\bar{y}\right)}{\sum_{i} \sum_{i \neq j} w_{i j}\left(\sum_{i}\left(y_{i}-\bar{y}\right)^{2}\right.}
$$

The average and variance of the Moran I coefficients are calculated as follows (Ward \& Gleditsch, 2011):

$$
\begin{gathered}
E(I)=-\frac{1}{(n-1)} \\
\operatorname{Var}(I)=\frac{n^{2}(n-1) \frac{1}{2} \sum_{i \neq j}\left(w_{i j}+w_{j i}\right)^{2}-n(n-1) \sum_{k}\left(\sum_{j} w_{k j}+\sum_{i} w_{i k}\right)^{2}-2\left(\sum_{i \neq j} w_{i j}\right)^{2}}{(n+1)(n-1)^{2}\left(\sum_{i \neq j} w_{i j}\right)^{2}}
\end{gathered}
$$

For calculated values (Arlinghaus et al., 1996):

- If the $\mathrm{MC}$ value is close to $+1^{\prime}$, there is a strong positive autocorrelation

- If the $\mathrm{MC}$ value is close to -1 , there is a strong negative autocorrelation

- If the $\mathrm{MC}$ value is close to $-1 /(\mathrm{n}-1)$, this value is random

\section{Selection of Regression Model}

\section{Spatial Autoregressive Model or Spatial Lag (SAR)}

The spatial autoregressive model measures the correlation of values at each location with values at neighboring locations. Spatial Autoregressive Model (SAR) or Spatial Lag Model (SLM) is a linear regression model in which there is a spatial correlation in the dependent variable. The general model for SAR is as follows: 


$$
\begin{gathered}
\gamma=\rho W \gamma+X \beta+\in, \\
\in ? \sim N\left(0, \sigma^{2} I\right),
\end{gathered}
$$

Spatial lag coefficient 0 indicates the level of correlation of the spatial influence of an area to other areas around it $\rho$ (Anselin, 1995).

\section{Spatial Error Model (SEM)}

SEM is a linear regression model in which in error there is a spatial correlation. The general model for SEM is as follows:

$$
\begin{gathered}
\gamma=X \beta+u, \\
u=\lambda W u+\varepsilon, \\
\varepsilon \text { ? } \sim N\left(0, \sigma^{2} I\right),
\end{gathered}
$$

The spatial error coefficient $(\boldsymbol{E})$ shows the correlation level of the influence of spatial error from one region to other areas around it (Anselin, 2005; Baltagi et al., 2003; LeSage \& Pace, 2009; Samadi et al., 2017).

\section{Result and Discussion}

\section{Identification of Spatial Effects and Moran's Index}

Spatial effects, namely spatial dependence, occur due to the correlation between regions consisting of lag dependence and spatial error. The results of the identification of spatial effects are shown in Table 5:

Table 5. Diagnostic tests for Spatial Effects and Moran Index

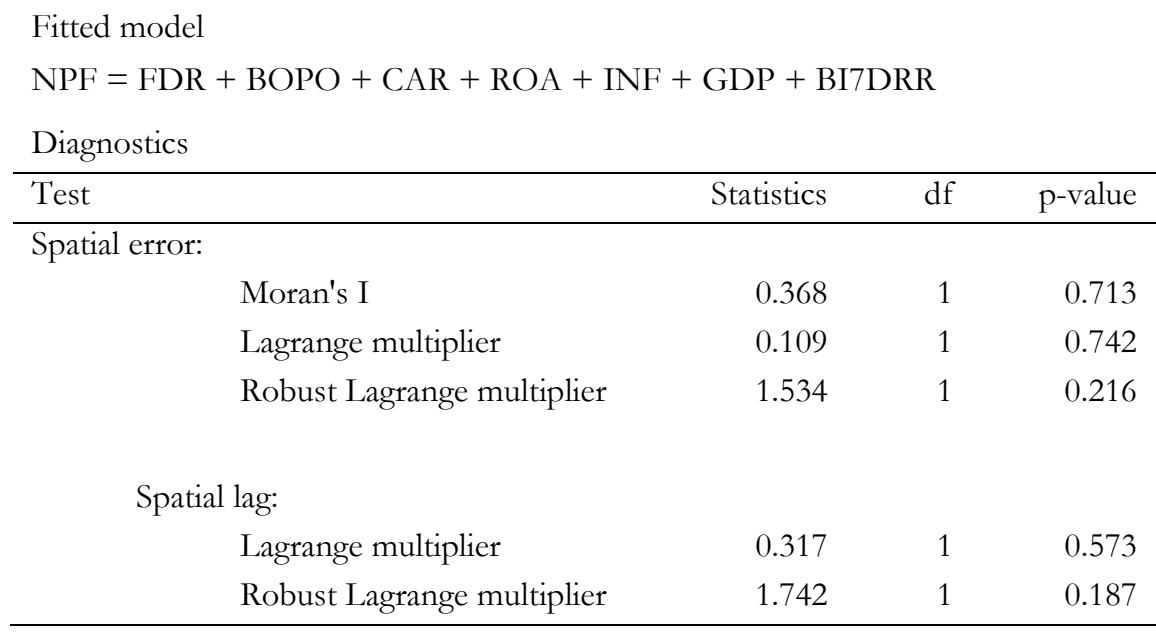

Based on Table 5, the Moran index is 0.368 with a p-value of $0.713>0.05$, so it can be concluded that there is a spatial autocorrelation between the locations of Islamic Commercial Banks. In addition, the p-value of LM in the spatial error model is 0.742 which is greater than and the p-value of LM in the spatial lag model is 0.573 , which is greater than apart from the LM value, it can also be seen from the Robust LM of 0.216 in the spatial error model and 0.187 in the spatial lag model, both of which have values above 0.05 . Hence, to choose the best model, it can be seen from the two LM values, because the value of the two models above 0.05 , then the lowest value is chosen, namely the spatial lag model LM. Therefore, the model used is the spatial lag model.

\section{Best Model Selection}

The criteria used to select the model are the AIC and $\mathrm{R}^{2}$ values. The model is considered to be good if it has a small AIC value and a larger $\mathrm{R}^{2}$ value. The table of model selection values shows that the smaller AIC value and the large $\mathrm{R}^{2}$ value are found in the SAR model (Arlinghaus et al., 1996; Baltagi et al., 2003). The analysis results found that the AIC value in the Regression model 
was 29.91445 with $\mathrm{R}^{2}$ value of 0.867 . Meanwhile, the AIC value in the SAR model is 26.49432, with $\mathrm{R}^{2}$ value of 0.868 . Meanwhile, in the SEM model, the AIC value is 26.65517 , and the $\mathrm{R}^{2}$ value is 0.867 . The value of the model selection shows that the smaller AIC value and the large $\mathrm{R}^{2}$ value are in the SAR model. Therefore, the model chosen to analyze the effect of Non-Performing Financing (NPF) on FDR, BOPO, CAR, ROA, Inflation, GDP and BI Rate is the SAR model.

\section{Spatial Autoregressive Model or Spatial Lag (SAR)}

The spatial autoregressive model measures the correlation of values at each location with values at neighboring locations. The data used is quarterly data from all BUS in Indonesia in 2015-2020. The total sample BUS is 7 banks, and the total data are 168 data. The SAR test results are shown in the Table 6:

Table 6. Results of Spatial Autoregressive Model (SAR)

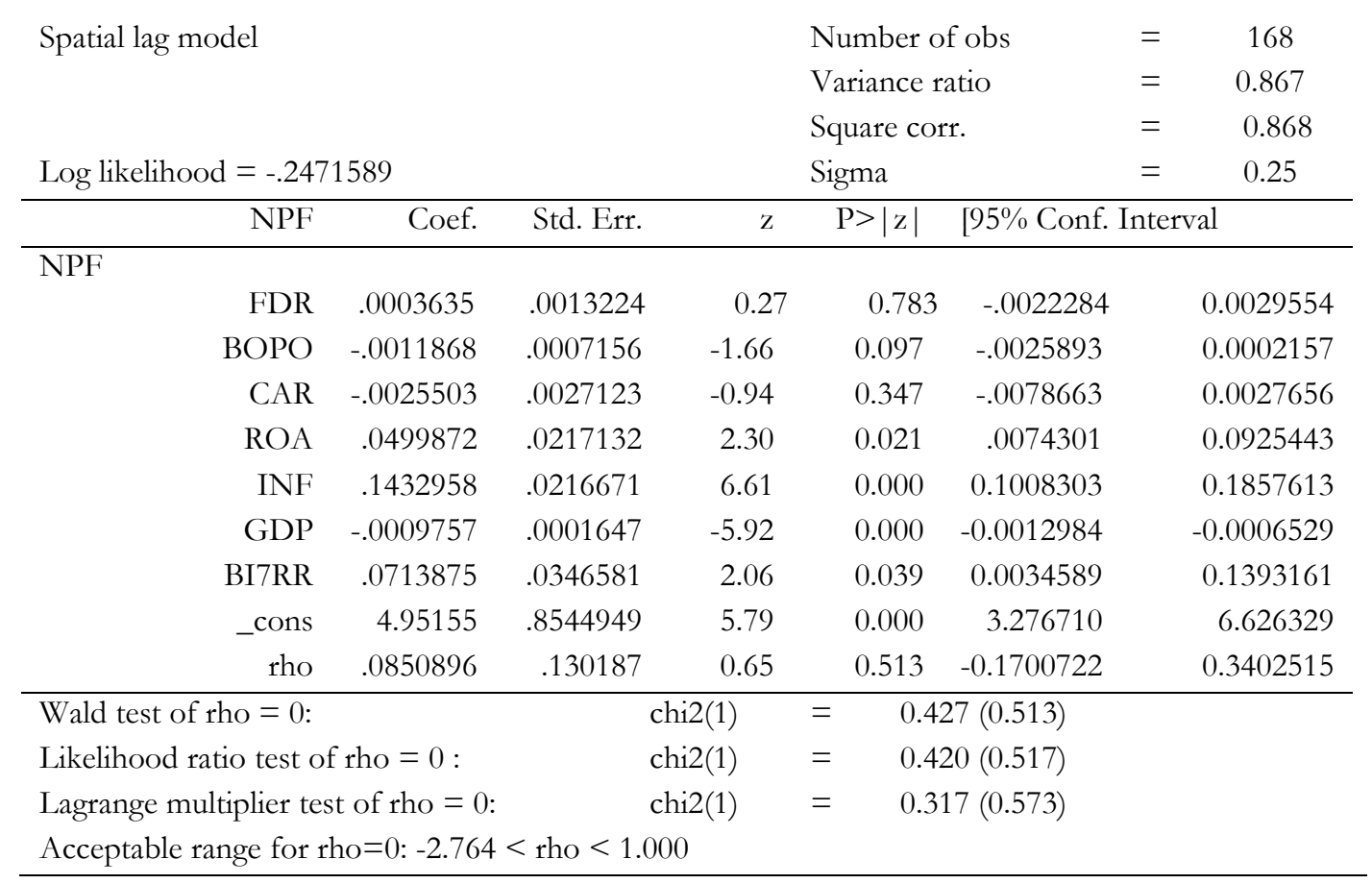

In the lag model test (SAR), the rho value used as a reference in the lag model shows a coefficient value of 0.0850896 with a probability value of 0.513 . The discussion on the spatial autoregressive model is only carried out for the ROA, Inflation, GDP, and BI7DRR variables. This is because in this study, only these four variables have a significant influence on the NonPerforming Financing of Islamic commercial banks (Dubé \& Legros, 2014; Li et al., 2007). Because insignificant variables only have a very small effect, their existence does not need to be interpreted.

Based on Table 6, it can be seen that there is no influence between FDR on NPF. This is evidenced by the probability value that is more than the level of significance $(\alpha=0.05)$, in other words $0.783>0.05$. Therefore, hypothesis 1 is rejected. This study could not prove the influence of the FDR variable on the NPF. The results of this study are in line with research conducted by Chandra and Haryanto (2016) based on the results of multiple linear regression analysis, which states that FDR shows a negative relationship with NPL, which means that this variable has no significant effect on NPL. The study stated that there were outliers in the research data so that there was less chance of significance due to the small sample size of 12 banks with high NPL values.

Based on the test results that have been described, it can be seen that there is an influence between BOPO on NPF. There is an influence between BOPO and NPF, meaning that a high BOPO level is an indication that financial performance in banking has decreased. To prevent the high level of BOPO in banks, it can be done with operational cost efficiency, by cutting the budget for activities that are deemed not important, it will save operational costs to be more efficient. The 
results of this study are in line with research conducted by Chandra and Haryanto (2016), and Santosa et al. (2014) which show the positive effect of the BOPO ratio on the NPL. The smaller the BOPO ratio means the more efficient the bank's operational performance in carrying out its daily operations so that the possibility of a bank in difficult conditions will be smaller.

This study failed to prove the effect of CAR on NPF. The CAR variable has no effect on the NPF based on the probability values that are more than the significance level $(\alpha=0.05)$, in other words $0.347>0.05$. Therefore, hypothesis 3 is rejected. This is possible because banks in managing their capital are not efficient. According to Bank Indonesia Regulation No. 13/3/PBI/2011, Bank Indonesia requires all banks to meet a capital adequacy ratio of $8 \%$ of RiskWeighted Assets (RWA) and if added with a capital buffer of $2.5 \%$, the value is $11.5 \%$. The CAR value for Islamic banks in Indonesia is an average of $20.58 \%$, far above the minimum requirement, and there are even banks that have a CAR above 30\%. This condition shows that banks are inefficient in managing their capital. The results of this study are in line with the research conducted by Auliani and Syaichu (2016) which states that CAR has a negative effect on NPF. They further explained that Islamic bank capital represented by the CAR ratio must be able to cover all business risks faced by banks, including the risk of losses that occur due to non-performing financing. Similarly, research conducted by Bondarenko et al. (2020), and Purwaningtyas and Hartono (2020) shows that the CAR has no significant effect on NPF.

There is an influence between ROA and NPF. This can be seen from the probability value that is less than the level of significance $(\alpha=0.05)$, in other words $0.021<0.05$. Therefore, hypothesis 4 is accepted. In theory, profitability is one of the important parameters to assess banking performance. High profit is a sign that the bank is performing well and will be a safe place for the public to place their funds. It is on their trust that the bank can collect a lot of funds which will then be channeled in the form of financing. The more financing that is successfully distributed, the NPF ratio can then be reduced. This research was supported by Chandra and Haryanto (2016), and Nugrohowati and Bimo (2019) which also stated that the ROA variable has a negative and significant effect on the level of NPF in BPRS in Indonesia.

There is an influence between inflation and NPF, it shows that the greater the sensitivity of inflation will affect the decrease in the NPF of Islamic banks. This is based on the probability value that is less than the significance level $(\alpha=0.05)$, in other words $0.000<0.05$. Therefore, hypothesis 5 is accepted. If it is associated with non-performing financing, it means that there is a lot of demand for goods that will encourage an increase in inflation. When at a certain point, with the fulfillment of the demand for goods, it is clear that inflation will decrease and economic activity will stagnate, businesses that have so far obtained financing from Islamic banks will have difficulty returning their principal financing. So it is said that the decline in the inflation rate will increase the NPF of Islamic banking (Auliani \& Syaichu, 2016). So if the NPF level is high, Islamic banks will reduce the distribution of funds in the real sector. The results of this study are in line with research conducted by Hosen and Muhari (2019) which states that inflation has a positive effect NPF.

Furthermore, there is an influence between GDP and NPF, if the GDP level rises then economic stability will trigger people to make loans to banks, so that if in a location more and more people apply for financing, the risk of non-performing financing will be even greater and will affect the stability of the banking system. Based on the data obtained in this study, the maximum GDP level of 4,067.8 billion was in the third quarter of 2019, and the minimum GDP level of 2,728 billion was in the first quarter of 2015. The GDP level tends to continue to increase in the last 5 years until 2020. What banks can do to reduce risks when there is an increase in GDP is to be more selective in channeling financing to the public and carry out the principle of prudence properly, to minimize the risk of non-performing financing in the future in the event of an economic shock. The results of this study are in line with research conducted performed by Auliani and Syaichu (2016), and Rahmah and Armina (2020) found that the GDP variable has a positive and significant effect on NPF.

Based on Table 7, it can be concluded that there is an influence between the BI Rate on NPF. There is an influence between the BI Rate and the NPF, which means: If the BI rate increases, Islamic banks will automatically adjust the profit-sharing rate because indirectly the BI rate 
becomes a reference for Islamic banks in determining the profit-sharing margin. A high profitsharing margin will reduce the interest of the mudharib to apply for financing because it will burden the mudharib with high installment costs. The results of this study are in line with research conducted by Naibaho and Rahayu (2018), which states that the BI rate has a positive and significant effect on the NPL of conventional banks. In line with the research conducted by Febrianti and Ashar (2016) states that the BI rate variable has a significant effect on the NPF level of Islamic banks.

\section{Conclusions}

Financing in Islamic banking is a driving factor for bank operations. With the increase in financing, the function of the bank as an intermediary institution can run well. This study used spatial analysis in the Islamic commercial banking sector in Indonesia. The results of the analysis show that based on the global distribution, there is a significant spatial effect through the geographical location between one bank and another, where the results have gone through a verification process based on the value of the Lagrange Multiplier coefficient and Moran Index. Analysis of factors that influence NPF in Islamic commercial banks in Indonesia in micro spatial terms is BOPO where the higher the BOPO, the smaller the non-performing financing. Meanwhile, the higher the ROA, the higher the non-performing financing. For the macroeconomy, it is influenced by inflation, GDP, and BI rate. The higher the inflation, the higher the NPF. Similarly, the higher the BI Rate, the greater the NPF. Meanwhile, the higher the GDP, the smaller the NPF.

Recommendations For further researchers, it is hoped that they will be able to use provincial data to see the spatial effect between provinces to obtain the spatial analysis between regions. The limitations of this study, related to the sample of Islamic banks, only examined those registered in OJK, not all Islamic banks in Indonesia. For further research, they could use a sample of all the existing Islamic banks in Indonesia.

\section{Author Contributions}

Conceptualization: Eko Suprayitno

Data curation: Rizky Mubarocha $\mathrm{H}$

Formal analysis: Rizky Mubarocha $\mathrm{H}$

Investigation: Rizky Mubarocha $\mathrm{H}$

Methodology: Eko Suprayitno

Project administration: Rizky Mubarocah H

Supervision: Eko Suprayitno

Validation: Eko Suprayitno

Visualization: Eko Suprayitno

Writing - original draft: Rizky Mubarocha $\mathrm{H}$

Writing - review \& editing: Eko Suprayitno

\section{References}

Ahmadi, K. A., Moh. Amin, \& Madi, R. A. (2017). Pengaruh makro ekonomi dan fundamental bank terhadap non performing loan. https://doi.org/10.31227/osf.io/kgw98

Amaroh, S. (2016). Tanggung jawab sosial bank syariah terhadap stakeholder dalam perspektif maqâshid syarîah. Abkam, Jurnal Ilmu Syariah, 16(1), 41-50. https://doi.org/10.15408/ajis.v16i1.2894

Amaroh, S., \& Masturin, M. (2018). The determinants of maqasid shariah based performance of Islamic banks in Indonesia. Iqtishadia, 11(2), 354-370. https://doi.org/10.21043/iqtishadia.v11i2.3961

Amiruddin, K. (2018). Kelayakan nasabah dalam pemberian pembiayaan kredit kepemilikan rumah pada kantor bank pembiayaan rakyat Syariah investama mega bakti Makassar. Al- 
Mashrafiyah: Jurnal Ekonomi, Keuangan, dan Perbankan Syariah, 2(2), 63-76. https://doi.org/10.24252/al-mashrafiyah.v2i1.6141

Angraini, D., Sudarsono, H., \& Anindita, S. (2020). The influence of financial performance and macroeconomic on financing risk in Islamic banks. Asian Journal of Islamic Management, 2(2), 138-152. doi:https://doi.org/10.20885/ajim.vol2.iss2.art6

Anselin, L. (1995). Local andicators of spatial association-LISA. Geographical Analysis, 27(2), 93115. https://doi.org/10.1111/j.1538-4632.1995.tb00338.x

Anselin, L. (2005). Exploring spatial data with GeoDaTM: A workbook (March 6). Center for Spatially Integrated Social Science. Retrieved from https://geodacenter.github.io/docs/geodaworkbook.pdf

Anselin, L. (2019). The Moran scatterplot as an ESD A tool to assess local instability in spatial association. In Spatial Analytical Perspectives on GIS (1st Editio, p. 16). Routledge. https://doi.org/10.1201/9780203739051-8

Arlinghaus, S. L., Griffith, D. A., Arlinghaus, W. C., Drake, W. D., \& Nystuen, J. D. (1996). Practical handbook of spatial statistics. Boca Raton (Fla.): CRC press. Retrieved from http://lib.ugent.be/catalog/rug01:000429635

Astrini, K. S., Suwendra, I. W., \& Suwarna, I. K. (2018). Pengaruh CAR, LDR dan bank size terhadap NPL pada lembaga perbankan yang terdaftar di Bursa Efek Indonesia. E-Journal Bisma Universitas Pendidikan Ganesha Jurusan Manajemen, 2(1), 1-8. Retrieved from https://ejournal.undiksha.ac.id/index.php/BISMA-JM/article/view/21977

Auliani, M. M., \& Syaichu. (2016). Analisis pengaruh faktor internal dan faktor eksternal terhadap tingkat pembiayaan bermasalah pada Bank Umum Syariah di Indonesia periode tahun 2010-2014. Diponegoro Journal of Management, 5(3), 559-572. Retrieved from https://ejournal3.undip.ac.id/index.php/djom/article/view/14644

Badria, M., \& Marlius, D. (2019). Analisis rasio likuiditas pada PT. Bank Perkreditan Rakyat (BPR) Lengayang. OSF Preprints, April 25, 1-11. https://doi.org/10.31219/osf.io/esvb7

Baltagi, B. H., Song, S. H., \& Koh, W. (2003). Testing panel data regression models with spatial error correlation. Journal of Econometrics, 117(1), 123-150. https://doi.org/10.1016/S03044076(03)00120-9

Boediono. (1999). Seri sinopsis pengantar ilmu ekonomi. No. 2. BPFE.

Bondarenko, E., Zhuravka, O., Aiyedogbon, J. O., Sunday, O. E., \& Andrieieva, V. (2020). Structural modeling of the impact of bank nonperforming loans on the banking sector: The Ukrainian experience. Banks and Bank Systems, 15(2), 67-78. https://doi.org/10.21511/bbs.15(2).2020.07

Chandra, E. K., \& Haryanto, A. M. (2016). Analisis pengaruh variabel kinerja bank (CAR, ROA, BOPO dan LDR), serta pertumbuhan kredit dan kualitas kredit terhadap Non Performing Loan (NPL). Diponegoro Journal of Management, 5(4), 108-120. Retrieved from https:// ejournal3.undip.ac.id/index.php/djom/article/view/17884

Dendawijaya. (2003). Manajemen Perbankan. Edisi Revisi Sembilan. Ghalia Indonesia.

Dubé, J., \& Legros, D. (2014). Spatial autocorrelation. In spatial econometrics using microdata (Issue 24 September 2014). John Wiley \& Sons, Inc. https://doi.org/10.1002/9781119008651.ch3

Fatoni, A., \& Utami, K. D. S. (2019). Pengaruh kinerja keuangan dan kondisi makroekonomi terhadap pembiayaan bermasalah BPR Syariah di Indonesia. Equilibrium: Jurnal Ekonomi Syariah, 7(2), 203-223. https://doi.org/10.21043/equilibrium.v7i2.5900

Febrianti, S. E., \& Ashar, K. (2016). Analisis pengaruh pertumbuhan GDP, Inflasi, BI Rate dan nilai tukar terhadap kredit bermasalah pada bank konvensional dan bank Syariah. Jurnal 
Ilmiah Mahasiswa FEB, 3(2), 1-14. Retrieved from https://jimfeb.ub.ac.id/index.php/jimfeb/article/view/1763

Hameed, S., Wirman, A., Alrazi, B., Nazli, M., \& Pramono, S. (2004). Alternative disclosure and performance measures for Islamic banks. Second Conference on Administrative Sciences: Meeting the Challenges of the Globalization Age, King Fahd University of Petroleum \& Minerals, Dhabran, Saudi Arabia. https://doi.org/10.1017/CBO9781107415324.004

Hernawati, H., \& Puspasari, O. R. (2018). Pengaruh faktor makroekonomi terhadap pembiayaan bermasalah. Journal of Islamic Finance and Accounting, 1(1), 29-44. https://doi.org/10.22515/jifa.v1i1.1134

Hosen, M. N., \& Muhari, S. (2019). Non-performing financing of Islamic rural bank industry in Indonesia. Banks and Bank Systems, 14(1), 20-28. https://doi.org/10.21511/bbs.14(1).2019.03

Kasmir. (2015). Analisis Laporan Kenangan. (Edisi Kedua). PT Raja Grafindo Persada.

Kuncoro, M. (2002). Manajemen perbankan: Teori dan aplikasi. Yogyakarta: BPFE.

LeSage, J., \& Pace, R. K. (2009). Introduction to spatial econometrics. Chapman and Hall/CRC. https://doi.org/10.1111/j.1467-985x.2010.00681_13.x

Li, H., Calder, C. A., \& Cressie, N. (2007). Beyond Moran’s I: Testing for spatial dependence based on the spatial autoregressive model. Geographical Analysis, 39, 357-375. https://doi.org/10.1111/j.1538-4632.2007.00708.x

Mahdi, F. M. (2019). Pengaruh instabilitas makroekonomi terhadap non-performing financing perbankan syariah di Indonesia. Falab: Jurnal Ekonomi Syariah, 4(2 (Agustus 2019)), 214 226. https://doi.org/10.22219/jes.v4i2.11190

Mariani, S., Wardono, Masrukan, \& Fauzi, F. (2017). The arcview and GeoDa application in optimization of spatial regression estimate. Journal of Theoretical and Applied Information Technology, 205(6), 1286-1299. Retrieved from http://www.jatit.org/volumes/Vol95No6/7Vol95No6.pdf.

Mazri, K. F., Ismail, R. F., Arshad, R., \& Kamaruzaman, S. A. (2018). Corporate governance attributes as determinants of the Islamic social reporting of Shariah-compliant companies in Malaysia. International Journal of Economics and Management, 12((S1)), 169-180.

Mufraini, M. A., Wicaksono, A. T. S., Meylianingrum, K., Ningtyas, M. N., \& Supriyono. (2020). Islamic bank financing: Finding the spatial effect and influencing factors from an archipelagic Indonesia. International Journal of Economic Policy in Emerging Economies, 13(1), $36-$ 51. https://doi.org/10.1504/IJEPEE.2020.106681

Mutia, E., Jannah, R., \& Rahmawaty, R. (2019). Islamicity performance index of Islamic banking in Indonesia. Advances in Social Science, Education and Humanities Research, 424-436. https://doi.org/10.2991/agc-18.2019.65

Naibaho, K., \& Rahayu, S. M. (2018). Pengaruh GDP, inflasi, BI rate, nilai tukar terhadap non performing loan pada bank umum konvensional di Indonesia. Jurnal Administrasi Bisnis (JAB), 62(2), 87-96. $\quad$ Retrieved from http://administrasibisnis.studentjournal.ub.ac.id/index.php/jab/article/view/2678

Nawaz, T., \& Haniffa, R. (2017). Determinants of financial performance of Islamic banks: an intellectual capital perspective. Journal of Islamic Accounting and Business Research, 8(2), 130 142. https://doi.org/10.1108/JIABR-06-2016-0071

Nopirin, P. (2004). Pengantar teori ekonomi moneter. Balai Pustaka Ekonomi UGM.

Nugrohowati, R. N. I., \& Bimo, S. (2019). Analisis pengaruh faktor internal bank dan eksternal terhadap Non-Performing Financing (NPF) pada Bank Perkreditan Rakyat Syariah di 
Indonesia. Jurnal Ekonomi dan Keuangan Islam, 5(1), 42-49. https://doi.org/10.20885/jeki.vol5.iss1.art6

OJK. (2019). Laporan kinerja 2019. Otoritas Jasa Keuangan. Retrieved from https://www.ojk.go.id/id/data-dan-statistik/laporan-kinerja/Documents/Laporan Kinerja OJK 2019.pdf

OJK. (2020). Statistik perbankan syariah - Sharia Banking Statistics. Otoritas Jasa Keuangan. Retrieved from https://www.ojk.go.id/id/kanal/syariah/data-dan-statistik/statistik-perbankansyariah/Default.aspx

Prasetyoningrum, A. K. (2015). Analysis BI rate and return of third party fund on rate of third party fund on Islamic banking in Indonesia. Conference In Business, Accounting, and Management

(CBAM), 2(1). Retrieved
http://jurnal.unissula.ac.id/index.php/cbam/article/view/296

Purwaningtyas, H., \& Hartono, U. (2020). Pengaruh GDP, inflasi, kurs, CAR, FDR, financing dan bank size terhadap NPF perbankan syariah di Indonesia tahun 2014-2017. Ilmu Manajemen, 8(21), 352-367. Retrieved from https://jurnalmahasiswa.unesa.ac.id/index.php/jim/article/view/31134

Putrama, A., \& Asandimitra, N. (2017). Pengaruh variabel makroekonomi terhadap profitabilitas bank non devisa di Indonesia periode 2012-2016. Jurnal Ilmu Manajemen (IIM), 5(2), 1-8. Retrieved

from https://jurnalmahasiswa.unesa.ac.id/index.php/jim/article/view/19930/18235

Putri, R. R. (2020). Pengaruh kurs dan produk domestik bruto terhadap pembiayaan perbankan syariah di Indonesia. Adl Islamic Economic, 1, 65-80. Retrieved from https://ejournal.steialfurqon.ac.id/index.php/adl/article/view/7

Rahmah, A. Z., \& Armina, S. H. (2020). Macro and micro determinants of the non-performing finance: The case of Indonesian Islamic bank. Jurnal Ekonomi dan Kenangan Islam, 6(1), 34 41. https://doi.org/10.20885/jeki.vol6.iss1.art4

Rahman, T. \& Fatmawati, K. (2020). The influence of financial ratios on non performing financing of the sharia rural banks of Special Region of Yogyakarta (BPRS DIY) period 2015 -_2018. Asian Journal of Islamic Management, 2(1), 25-35. https://doi.org/10.1108/AJIM.vol2.iss1.art3

Reksoprayitno, S. (2000). Ekonomi makro: Pengantar analisis pendapatan nasional. Edisi Kelima, Cetakan Kedua, Liberty, Yogyakarta.

Samadi, H., Asdi, Y., \& Effendi. (2017). Penerapan model regresi spasial dalam menentukan faktorfaktor yang mempengaruhi indeks pembangunan. Jumal Matematika UNAND, 6(4), 80-89. https://doi.org/https://doi.org/10.25077/jmu.6.4.80-89.2017

Santosa, S. B., Sudarto, \& Sunarko, B. (2014). Analisis pengaruh LDR, BOPO, Size, LAR dan NIM terhadap NPL pada BPR konvensional di wilayah Jawa Tengah (periode 2010 -2012). Jurnal Ekonomi Bisnis dan Akuntansi, 4(1), 687-699. Retrieved from http://jp.feb.unsoed.ac.id/index.php/sca-1/article/view/710

Sudarsono, H., \& Saputri, M. A. (2018). The effect of financial performance toward profit-sharing rate on mudharabah deposit of Sharia banking in Indonesia. Muqtasid, 9(1), 82-92. http://dx.doi.org/10.18326/muqtasid.v9i1.82-92

Usanti, T. P. \& Shomad, Abd. (2013). Transaksi bank syariah. Bumi Aksara

Ward, M., \& Gleditsch, K. (2011). Spatial regression models. In Quantitative Applications in the Social Sciences (Second ed). Sage Publications. https://doi.org/10.4135/9781412985888

Wibowo, S. A., \& Saputra, W. (2017). Pengaruh variabel makro dan mikro ekonomi terhadap pembiayaan bermasalah pada bank syariah di Indonesia. Jurnal Ilmiah Akuntansi, 2(1), 96- 
112. https://doi.org/10.23887/jia.v2i1.10040

Widarjono, A., \& Rudatin, A. (2021). Financing diversification and Indonesian Islamic bank's nonperforming financing. Jurnal Ekonomi and Keuangan Islam, 7(1), 45-58. https://doi.org/10.20885/jeki.vol7.iss1.art4

Wiyadi, Meilani, S. E. R., Trisnawati, R., \& Pramesti, W. (2016). The Sharia banking performance based on Islamic indices in the ASEAN countries. Malaysia Indonesia International Conference on Economics, Management and Accounting. Retrieved from https://publikasiilmiah.ums.ac.id/handle/11617/8126

Yulianto, A., \& Solikhah, B. (2015). The internal factors of Indonesian sharia banking to predict the mudharabah deposits. Review of Integrative Business and Economics Research Online, 5(1), 210 218. Retrieved from https://sibresearch.org/uploads/3/4/0/9/34097180/riber_h15125_210-218.pdf 